\title{
Nowe aspekty badań nad chemizmem gleb aglomeracji łódzkiej w oparciu o metody GIS
}

\section{New aspects of research into the chemical composition of soils in the Łódź agglomeration, based on GIS methods}

Zarys treści

\begin{abstract}
Praca zakłada wykorzystanie starych map, wydanych w formie drukowanej, do prowadzenia analiz przestrzennych w środowisku GIS. Informacje w formie danych punktowych o stężeniach pierwiastków śladowych w glebach aglomeracji łódzkiej zostały zdigitalizowane, a następnie poddane procesowi interpolacji. Artykuł zawiera opisy kolejnych etapów działań realizowanych w celu uzyskania wyników w formie cyfrowej, jak najbardziej zbliżonej do danych zawartych w atlasie geochemicznym. Powstała geobaza będzie służyć do prowadzenia analiz przestrzennych, mających na celu wyznaczenie obszarów o różnym stopniu zanieczyszczenia metalami ciężkimi, jak również zasobności w składniki pokarmowe.
\end{abstract}

Słowa kluczowe GIS, gleby aglomeracji, digitalizacja analogowych map gleb.

Abstract

The study assumes the use of old printed maps for conducting spatial analyses in the GIS environment. Information, in the form of point data on concentration of trace elements in soils of the tódź agglomeration, was digitalised and then interpolated. The article includes descriptions of subsequent stages of operations performed in order to obtain digital results, as close as possible to data included in the geochemical atlas. The resultant geobase will be used for conducting spatial analyses aimed at delimiting areas of various degree of both heavy metal pollution and nutrient richness.

Keywords

GIS, agglomeration soils, digitalisation of analogue soil maps.

\section{Wprowadzenie}

\subsection{Zakres badań}

Procesy wietrzenia skał macierzystych, a także działalność przemysłowa determinują występowanie metali ciężkich w glebach całego świata, a wzrost ich stężeń spowodowany jest głównie przez działalność antropogeniczną. Jest to wyraźnie zauważalne od początku XX wieku (Cutillas-Barreiro i in. 2016). Metale ciężkie w glebach mają wielki wpływ na zdrowie i życie ludzi oraz na integralność ekosystemów. Akumulacja metali ciężkich w glebach miejskich jest procesem złożonym i dynamicznym (Peng i in. 2017). Pierwiastki śladowe, takie jak: arsen, kadm, cynk, nikiel, ołów, miedź czy rtęć są uznawane za najbardziej wpływające na większość procesów biologicznych w glebie (Lucisine i in. 2015; Qing i in. 2015; Gaspéri i in. 2016; Hao i in. 2016). Od czasu intensywnej działalności przemysłowej człowieka notowane są podwyższone zawartości metali ciężkich w glebach miejskich. Wpływają one negatywnie na środowisko i ekosystemy miasta, powodując ograniczenie wzrostu roślin i przyczyniając się do akumulacji metali w ich tkankach (Laskowski i in. 2001; Cutillas-Barreiro i in. 2016). Gleby z wysoką zawartością materii organicznej są mniej narażone na negatywne oddziaływanie, mimo iż akumulują więcej pierwiastków śladowych w obszarach intensywnej działalności człowieka (Qing i in. 2015). Jednak wielu badaczy zauważyło odwrotną zależność, np. wraz ze wzrastającą zawartością substancji organicznej rośnie udział łatwo dostępnych dla roślin form miedzi i ołowiu (Kabata-Pendias i in. 1995; Niewiadomski, Tołoczko 2005; Niedbała i in. 2010; Kabata-Pendias, Szteke 2012).

Wreszcie zwraca się uwagę na rosnące zawartości metali ciężkich w glebie ze względu na ich negatywny wpływ na ekosystemy polowe oraz na zdrowie człowieka (wysoka toksyczność i zdolność do łatwej bioakumulacji). Intensywność emisji z ognisk antropogenicznych może zaburzyć naturalny cykl biogeochemiczny metali ciężkich w środowisku glebowym (Laskowski, Tołoczko 2001; Niewiadomski i in. 2010; Cutillas-Barreiro i in. 2016).

Proces skażenia gleb, w porównaniu do innych elementów środowiska, jest procesem długotrwałym, trudnym do monitorowania i często niejednoznacznym. Nadmierna akumulacja metali ciężkich w glebach prowadzi do pogorszenia działania ekosystemu glebowego, co można zaobserwować u roślin rosnących na zanieczyszczonych glebach, co skutkuje redukcją wzrostu i zmniejszeniem efektywności procesu fotosyntezy i utleniania (Kabata-Pendias, Pendias 1999; Gorlach, Mazur 2002). Pierwiastki śladowe wpływają również na kluczowe mikroorganizmy obniżając wydajność procesów, w których biorą udział, wpływając pośrednio na zdrowie człowieka i tworząc inne problemy środowiskowe. Dlatego zanieczyszczenie metalami ciężkimi w glebach jest rosnącym problemem w zarządzaniu środowiskiem w miastach (Czarnowska 1997; Laskowski, Tołoczko 1998). 
Wyznaczenie geochemicznego tła, progu dla pierwiastków śladowych w glebach i identyfikacja nagromadzeń (stref koncentracji) z ognisk zanieczyszczeń punktowych, jest kluczowym procesem w zarządzaniu jakością gleb (Czarnowska 1996). W celu ochrony gleb, w różnych krajach przyjęto wartości graniczne dla stężeń metali ciężkich. Stosowane wskaźniki powinny być dobrane odpowiednio do warunków środowiskowych, ponieważ bioróżnorodność wpływa bezpośrednio na biodostępność metali ciężkich, czyli na ich toksyczność w środowisku i wpływ na organizmy (Qing i in. 2015). Czynnikami wpływającymi na mobilność metali ciężkich w glebach są m.in. skład mineralogiczny, odczyn, pojemność wymienna kationów, zawartość materii organicznej, tekstura, typ gleby czy sposób jej użytkowania (Bednářová i in. 2016). Wzajemne relacje wszystkich wymienionych powyżej elementów powinny stanowić bazę do oceny, jakości chemizmu gleb. W tym celu należy wyznaczyć poziomy zanieczyszczeń na różnych szczeblach według ich ilości. Wymaga to określenia poziomu naturalnej równowagi chemicznej gleby, w drugiej kolejności poziomu równowagi chemicznej gleby poddanej wpływom antropogenicznym, które ograniczają naturalne funkcje gleby i wreszcie określenia granicy poziomu pełnego zanieczyszczenia chemicznego gleby (Kabata-Pendias i in. 1995).

\subsection{Metale ciężkie w glebach aglomeracji łódzkiej}

Zawartość metali ciężkich w glebach aglomeracji łódzkiej należy do tematów badawczych podejmowanych przez wielu autorów (Laskowski, Tołoczko 1995; Czarnowska 1997; Niedbała i in. 2010). Zagadnienie było poruszane przede wszystkim w kontekście porównania do naturalnych koncentracji wybranych pierwiastków. Przyrównanie to prowadzono bez podziału ze względu na typy gleb, ponieważ jak wykazały badania, zróżnicowanie występowania danych pierwiastków jest częściej łączone z uziarnieniem gleb niż ich genezą (Czarnowska, Walczak 1988; Laskowski, Tołoczko 1995; Czarnowska 1997).

Poszerzenie granic Łodzi i wzrost ilości mieszkańców powodowany był m.in. rozwojem działalności przemysłowej oraz rozszerzaniem wielu podstawowych aktywności gospodarczych, które uwidoczniły się w mieście wyjątkowo silnie $\mathrm{w}$ drugiej połowie XIX wieku. Taki rozwój był korzystny dla Łodzi i dla jej mieszkańców, lecz wpływał negatywnie na środowisko przyrodnicze. W aspekcie gleb negatywny wpływ zaznacza się nie tylko poprzez depozycję pyłów emitowanych z lokalnych zakładów przemysłowych, a także sposobem zagospodarowania terenu, ubytkiem powierzchni naturalnych, coraz gęściejszej zabudowy: powstających fabryk, budynków mieszkalnych z coraz większą ilością palenisk i powiększającej się sieci ulic. Jednak to zakłady przemysłowe oraz komunikacja i transport samochodowy wpływają najbardziej negatywnie na środowisko glebowe obecnej aglomeracji łódzkiej (Laskowski, Tołoczko 1998, 2003; Laskowski i in. 2005b; Niedbała i in. 2010).

Różnego rodzaju odpady były zakopywane w miejscach po wyrobiskach lub bezpośrednio w glebie, w obrębie lokalizacji, które po kilkudziesięciu latach pojawiały się już w nowych granicach miasta. W przypadku wprowadzenia do gleby substancji toksycznych i pospolitych odpadów chemicznych prowadziło to do zanieczysz- czenia nie tylko środowiska glebowego i utrudnienia procesów biologicznych organizmom żyjącym w glebie, ale także do skażenia innych elementów ekosystemu, w tym wód powierzchniowych i podziemnych. Szczególnie ucierpiały rzeki przepływające przez aglomerację, czyli Ner w Łodzi, Bzura w Zgierzu i Dobrzynka w Pabianicach (Laskowski i in. 2005a, 2006; Sobolewski, Tołoczko 2007; Trawczyńska, Tołoczko 2005a, 2005b, 2006; Wroński, Tołoczko 2008). Przy zanieczyszczeniach gleb aglomeracji łódzkiej najczęściej zauważalne są wpływy: zakładów przemysłowych, substancji ropopochodnych, pestycydów, metali ciężkich, a także znacznych ilości soli, zazwyczaj jako odcieki z dróg w okresach pozimowych (Laskowski, Tołoczko 2001; Tołoczko i in. 2009).

Gleby miejskie okolic Zgierza, w północnej części aglomeracji łódzkiej, w latach 1955-1995 były narażone na infiltrację wód zawierających metale ciężkie w dolinie rzeki Bzury. W Zgierzu prężnie rozwijał się przemysł chemiczny, a jego konsekwencją było zanieczyszczenie wód powierzchniowych niesionych przez Bzurę poniżej Zgierza. Spowodowało to również skażenie gleb w dolinie górnej Bzury (Trawczyńska i in. 2009). Stan wód powierzchniowych znacznie poprawił się w całej aglomeracji łódzkiej wraz ze schyłkiem przemysłu chemicznego i włókienniczego na tym obszarze. Poprawa jakości wody została odnotowana w badaniach Neru i Dobrzynki, a przykładem najbardziej pozytywnym mogą być wody Bzury i skutecznie zrealizowany projekt rewitalizacji jej doliny (Sobolewski, Tołoczko 2007; Niewiadomski, Tołoczko 2009).

W przypadku całego regionu łódzkiego (zbliżony powierzchnią do województwa łódzkiego), analizując okresy 10-letnie można zauważyć coraz mniejszy wpływ zanieczyszczeń na gleby aglomeracji łódzkiej (Niewiadomski, Tołoczko 2014). Mimo zmieniających się procesów w gospodarce, to nadal transport samochodowy i nierozwiązany problem niskich emitorów, czyli palenisk węglowych w mieszkaniach i domach mieszkańców Łodzi, Zgierza i Pabianic mają największy udział w skażeniu gleb obszaru badań (Czarnowska 1997; Laskowski i in. 2001).

\subsection{GIS w gleboznawstwie i naukach o glebach}

„System informacji przestrzennej - system pozyskiwania, przetwarzania i udostępniania danych, w którym zawarte są informacje przestrzenne i towarzyszące im informacje opisowe o obiektach. Jeśli dane odniesione są do środowiska geograficznego, to jest to system informacji geograficznej" - (cyt. za: Jerzy Gaździcki 1990, [w:] Gotlib i in. 2007). Początki wykorzystania technologii GIS (z ang. Geographic Information System), czyli Geograficznego Systemu Informacji sięgają początków lat 80. XX wieku. Pierwsze zastosowania systemu polegały na szukaniu ścieżek rozwiązań dla problemów przestrzennych. Niestety, początkowe możliwości pozwalały na uzyskanie wyników analiz cechujących się niewielką dokładnością, co było dodatkowo utrudnione przez małą dostępność danych. Obecnie wraz z rozwojem technologii i ulepszeniem systemów informacji geograficznej, dokładność i wiarygodność analiz przestrzennych stale rośnie, co z kolei odzwierciedla się w coraz to szerszym ich zastosowaniu w badaniach naukowych (Longley i in. 2006). 
Systemy GIS składają się w pierwszej kolejności ze specjalistycznego oprogramowania, następnie urządzeń je obsługujących oraz osób wyspecjalizowanych w tworzeniu i użytkowaniu każdego z elementów. Dodatkowo, w systemach muszą zaistnieć odpowiednie dane, algorytmy do przetwarzania, a także procedury związane z przekazem informacji. Zdecydowaną zaletą tych systemów jest ich wszechstronność w prowadzeniu analiz przestrzennych oraz sposobów ich prezentacji. Geograficzny system informacji znajduje zastosowanie m.in. w administracji, ochronie środowiska, planowaniu przestrzennym, monitoringu zanieczyszczeń, ochronie zdrowia, zarządzaniu kryzysowym, ratownictwie, transporcie i logistyce, wojsku, rolnictwie, geologii, kartografii, geomarketingu, systemach lokalizacyjnych, edukacji i nauce (Bielecka 2006; Urbański 2012).

GIS w naukach o glebach przejawia się m.in. w zastosowaniach na potrzeby precyzyjnego rolnictwa. Na przykład, mając dane o parametrach gleby z danych punktów pola uprawnego, operator sprzętu rolniczego ma możliwość aplikacji odpowiedniej dla potrzeb nawozowych ilości nawozu (Gotlib i in. 2007; Bielecka, Maj 2009). Większość analiz glebowych w systemach GIS jest oparta o wykorzystanie cyfrowego modelu terenu DEM, danych ze skaningu laserowego oraz zdjęć satelitarnych (Urbański 2012). Inne przykłady zastosowań narzędzi GIS w naukach o glebach i rolnictwie to: planowanie zbiorów, identyfikacja obszarów narażonych na suszę, monitorowanie upraw zagrożonych powodzią i gleb zagrożonych erozją, mapowanie żyzności gleby, przewidywanie wielkości plonów, inwentaryzacja typów gleb, tworzenie map rolniczych.

\section{Pozyskanie i przetwarzanie danych wejściowych}

\section{1. Źródło danych i jego ocena}

Źródłem danych parametrów glebowych był Atlas geochemiczny aglomeracji łódzkiej - część I: Gleby, osady wodne, wody powierzchniowe w skali 1:100 000, wykonany w Państwowym Instytucie Geologicznym w 1998 r. przez Józefa Lisa i Annę Pasieczną (1998), wydany przez Wydawnictwo Kartograficzne Polskiej Agencji Ekologicznej. Swoim zasięgiem obejmuje zarówno Łódź, jak i miasta znajdujące się w jego sąsiedztwie: Aleksandrów Łódzki, Konstantynów Łódzki, Pabianice, Stryków i Zgierz. Do pracy wykorzystano część l, prezentującą stan chemizmu gleb w granicach miast oraz terenów do nich przyległych zarówno użytków rolnych, jak i leśnych. Słuszność wykorzystania tego typu danych możemy potwierdzić słowami autorów cyt: „Atlasy i mapy geochemiczne aglomeracji miejskich stanowią podstawę ustalania zasięgu i przyczyn ewentualnych skażeń pochodzenia naturalnego lub antropogenicznego" (Lis, Pasieczna 1998).

Obszar opróbowania wynosi 1249 km². Próbki z badanego obszaru pobierano w siatce jednokilometrowej - 1 punkt na $1 \mathrm{~km}^{2}$. Warto zaznaczyć, że w porównaniu do gęstości sieci wykorzystywanych w innych krajach Europy, np. Cypr - 1 punkt na minimum $1 \mathrm{~km}^{2}$ przy 5350 stanowiskach, Anglia i Irlandia Północna - od 1 punktu na $0,25 \mathrm{~km}^{2}$ do 1 punktu na $25 \mathrm{~km}^{2}$ przy ponad 40000 stanowiskach, Francja - 1 punkt na 16 km² przy 2200 stanowiskach, Hiszpania - 1 punkt na $8 \mathrm{~km}^{2}$ przy 624 stano- wiskach (Bednářová i in. 2016), charakteryzuje się wysoką szczegółowością, a zarazem jakością wyników na mapach.

Atlas geochemiczny aglomeracji łódzkiej stanowi główne źródło danych niniejszej pracy. Do prac wykorzystano również mapy topograficzne z zasobów Biblioteki Wydziału Nauk Geograficznych oraz serwerów WMS, dane CODGiK udostępniane bez opłat, m.in. granice miast, powiatów, gmin i obrębów ewidencyjnych, drogi i numeryczny model terenu o rozdzielczości co najmniej 100 metrów. Warstwę pokrycia terenu wykonano w oparciu o dane Corine Land Cover z portalu: clc.gios.gov.pl.

\subsection{Metody badań}

Wybór narzędzi informatycznych i analitycznych wykonany został w oparciu o szereg testów mających wyłonić z nich te najbardziej optymalne. W przypadku aplikacji GIS, zdecydowano się na wykorzystanie oprogramowania ESRI ArcGIS. Procedura ta pozwoliła na ominięcie przeszkód wynikających z niekompatybilności różnych programów, jak i ewentualnych różnic w działaniu algorytmów służących do wybranych analiz przestrzennych. Poniżej zamieszczono krótki opis przeprowadzonych procedur mających na celu pozyskanie i przetworzenie materiałów źródłowych.

\section{Etap I. Skanowanie map}

Pierwszym etapem pracy było uzyskanie map przedstawiających interpolację stężenia danego pierwiastka $w$ formie cyfrowej. Istotne było uzyskanie niezniekształconego obrazu w wysokiej rozdzielczości i przy zachowaniu źródłowej skali barw, znajdujących się na mapie drukowanej. Strony atlasu geochemicznego są w formacie większym do A3. Zeskanowanie arkuszy tej wielkości, przy zachowaniu wyżej wymienionych parametrów, wymagało zastosowania skanera wielkoformatowego. Mapa została zeskanowana w rozdzielczości 600 dpi (punktów na cal), gdzie uzyskano raster 10592x8976 pikseli, który zapisano w formacie TIFF (Tagged Image File Format). Format ten pozwala na zapisanie obrazu zawierającego dużo więcej rozpiętości kolorów niż w przypadku JPEG. Rozpiętość tą określa się ilością bitów na kanał. Kanały są trzy: czerwony, zielony i niebieski. W każdym z nich można zapisać pewną ilość pochodnych odcieni. Im więcej ich można pomieścić, tym subtelniejsze przejścia tonalne i więcej kolorów zawartych będzie na fotografii. Taki format w środowisku ArcMap pozwala na modyfikację zakresów danych kanałów głównych barw składowych R (red), G (green), B (blue), co będzie istotne w procesie dalszej obróbki map.

Etap II. Nadawanie odniesienia przestrzennego

Kolejnym krokiem było określenie optymalnego układu odniesienia przestrzennego, do którego zostaną przetworzone dane źródłowe, a następnie będą prowadzone prace analityczne. Za optymalny wybrano Państwowy Układ Współrzędnych Geodezyjnych 1992 (PUWG 1992). Jest to układ jednostrefowy i w przypadku analiz geograficznych dla terenów położonych w Polsce Środkowej ma największą użyteczność.

Z uwagi na powyższe, układ projektu w ESRI ArcMap ustawiono na PUWG 1992. Następnie dodano pierwszą warstwę z obszarem badań oraz mapę topograficzną 
Polski poprzez serwer WMS (Web Map Service): geoportal.gov.pl. Warstwa WMS, jako posiadająca odpowiednie odniesienie przestrzenne dla tego terenu, pozwoliła na rozpoczęcie procedury nadawania odniesienia przestrzennego. Proces ten polegał na dopasowaniu rozpoznawalnych obiektów ze skanów map z ich odpowiednikami widocznymi na ortofotomapach z serwisów WMS. W przypadku map źródłowych (skany), za najbardziej przydatny okazał się ich podkład topograficzny. Wybór podobnych punktów odbywał się poprzez połączenie np. skrzyżowań dróg istniejących z tymi znajdującymi się na mapie topograficznej. W celu jak najlepszego dopasowania mapy, punkty wybierano zarówno w obszarach centralnych, jak i skrajnych obejmujących każdy z rogów obrazu. Efektem końcowym było utworzenie tabeli składającej się z 20 połączeń o najniższym błędzie. W przypadku pozostałych 9 map źródłowych, posłużono się obrazem z wcześniej nadaną georeferencją (ze względu na taki sam rozmiar każdego z obrazów). Każdy kolejny był dopasowywany do pierwszego na podstawie 4 punktów znajdujących się w narożnikach ramki danych, co znacznie ułatwiło i przyspieszyło daną procedurę. Ostatecznie uzyskano 10 obrazów nałożonych na siebie wpasowanych w mapę topograficzną z serwera WMS.

\section{Etap III. Pobranie danych z map źródłowych}

Założeniem tego etapu prac było automatyczne odczytanie danych z map źródłowych o zawartości pierwiastków znajdujących się w glebie, na podstawie przybliżonych punktów poboru wykonanych przez PIG. Posłużyła temu wybrana mapa z naniesionymi kwadratami przedstawiającymi przybliżone miejsce poboru próbki gleby.

W celu pobrania konkretnych wartości utworzono geobazę plikową zawierającą warstwę punktową. Punkty nanoszone były na każdy z kwadratów, przy czym starano się wybierać jego punkt środkowy (ryc. 1A), aby uzyskać wartości z uśrednionym błędem wynikającym z braku informacji o precyzyjnym miejscu poboru próbki. Wynikiem było utworzenie 1123 obiektów punktowych, gdzie kwadraty, które znacząco nachodziły na siebie zostały zaklasyfikowane jako ten sam punkt.

Etap IV. Przeniesienie punktów poza napisy i sygnatury Wyznaczone wcześniej środki kwadratów, podczas próby kolejnych etapów, wykazały niedoskonałość tej metody wynikającej z pokrywania się punktów w niektórych przypadkach z sygnaturami podkładu topograficznego, takimi jak drogi, napisy i liczby. Tworzyło to w miejscu punktu odmienne wartości pikseli od tych właściwych wyznaczonych podczas interpolacji. Istotnym okazało się sprawdzenie i przesunięcie punktów w miejsca występowania pikseli odpowiadającym tylko wartościom interpolacji, co odpowiadało danemu kolorowi z wyznaczonej na mapie skali. Był to istotny krok ze względu na pobieranie wartości na podstawie lokalizacji punktów (ryc. 1B).

Etap V. Filtracja obrazów rastrowych map (usunięcie różnic kolorów)

Kolejny etap zakładał filtrację samego obrazu w celu uśrednienia wartości pikseli sąsiadujących i uzyskaniu w ten sposób ujednoliconych kolorów. Różnice wynikały głównie ze specyfiki samego druku map, co po przybliżeniu zeskanowanej mapy widoczne jest w postaci jej ziarnistości (ryc. 1C). Istotne z punktu analizy obrazów było usunięcie właśnie tych zakłóceń. Wykorzystano do tego narzędzie do analizowania obrazu, z którego wybrano w opcjach przetwarzania filtr wygładzający $5 \times 5$. Zastosowanie filtra pozwoliło uzyskać obraz bez widocznych pikseli, a różnice w kolorach zostały uśrednione (ryc. 1D). W celu uzyskania najbardziej jednorodnych kolorów w danym przedziale, zastosowano ponownie filtr wygładzający $5 \times 5$ na sfiltrowanym uprzednio obrazie, dzięki czemu uzyskano obraz niewyraźny, lecz o ujednoliconych kolorach (ryc. 1E).

Etap VI. Klasyfikacja po kolorach z pierwotnych map Wykonanie filtracji na wszystkich mapach z interpolacją pozwoliło na wykonanie klasyfikacji opartej na kolorach oznaczających daną klasę, która przedstawia dany zakres wartości pierwiastka w glebie. Do tego celu wykorzystano narzędzie klasyfikacji obrazu. W pierwszym etapie zastosowano klasyfikację nienadzorowaną, która miała samodzielnie określić, do jakiej klasy należeć będzie dany piksel. Powinna to ułatwić wcześniej wykonana filtracja obrazu. Klasyfikacja nienadzorowana tworzyła więcej klas od tych znajdujących się na mapie oraz wyznaczała je z niewielką dokładnością tworząc grupy pikseli należące do innej klasy. Zastosowanie klasyfikacji nadzorowanej zdecydowanie poprawiło wyniki klasyfikacji. Podczas tej procedury, manualnie zostały wyznaczone pola wzorcowe dla każdej grupy pikseli dla danego przedziału. Ważne również okazało się utworzenie oddzielnej klasy dla ramki danych zawierającej wartości stopni oraz legendę mapy. Stanowczo zmniejszyło to wyznaczanie obszarów danej klasy w innej.

Pomimo niedokładności wyniku klasyfikacji widocznego na zbliżeniu (ryc. 2), wcześniejsza operacja przesunięcia punktów poza obręb znaków i napisów zawartych na mapie ma znaczenie, ponieważ punkty, na podstawie których wartości interpolacji będą pobierane, znajdują się w obszarach o minimalnej ilości błędów klasyfikacji, co umożliwi pobranie właściwych wartości.

\section{Etap VII. Pobranie wartości z klasyfikacji do tabeli atrybu-} tów

Kolejnym krokiem było pobranie wartości klas wyznaczonych podczas klasyfikacji do wcześniej utworzonej warstwy punktowej. Pomimo pierwotnie widocznych błędów nie stanowią one problemu, ponieważ błędy klasyfikacji pojawiały się głównie w miejscach występowania sygnatur, co zostało rozwiązane w poprzednich krokach.

W celu pobrania wartości danych pikseli, z klasyfikacji wybrano narzędzie pobierania wielu wartości do punktów (Extract multi values to points). Narzędzie to pozwala na pobranie wartości pikseli z określonego obrazu do warstwy punktowej, gdzie każdemu punktowi zostaje przypisana wartość ze względu na jego położenie na danej klasie. Jeżeli punkt występował w pobliżu dwóch lub więcej klas, wartości pikseli były interpolowane do wartości najczęściej występującej wokół punktu, co pozwoliło na wybranie opcji dwuliniowej interpolacji zawartej w narzędziu. Warto zauważyć, że narzędzie utworzyło tabelaryczną bazę danych punktów dla wszystkich dziesięciu klasyfikowanych obrazów. Wartości w tabeli ukazują te wcześniej utworzone podczas klasyfikacji nadzorowanej. Są to syntetyczne wartości utworzone na podstawie skali danej mapy. 


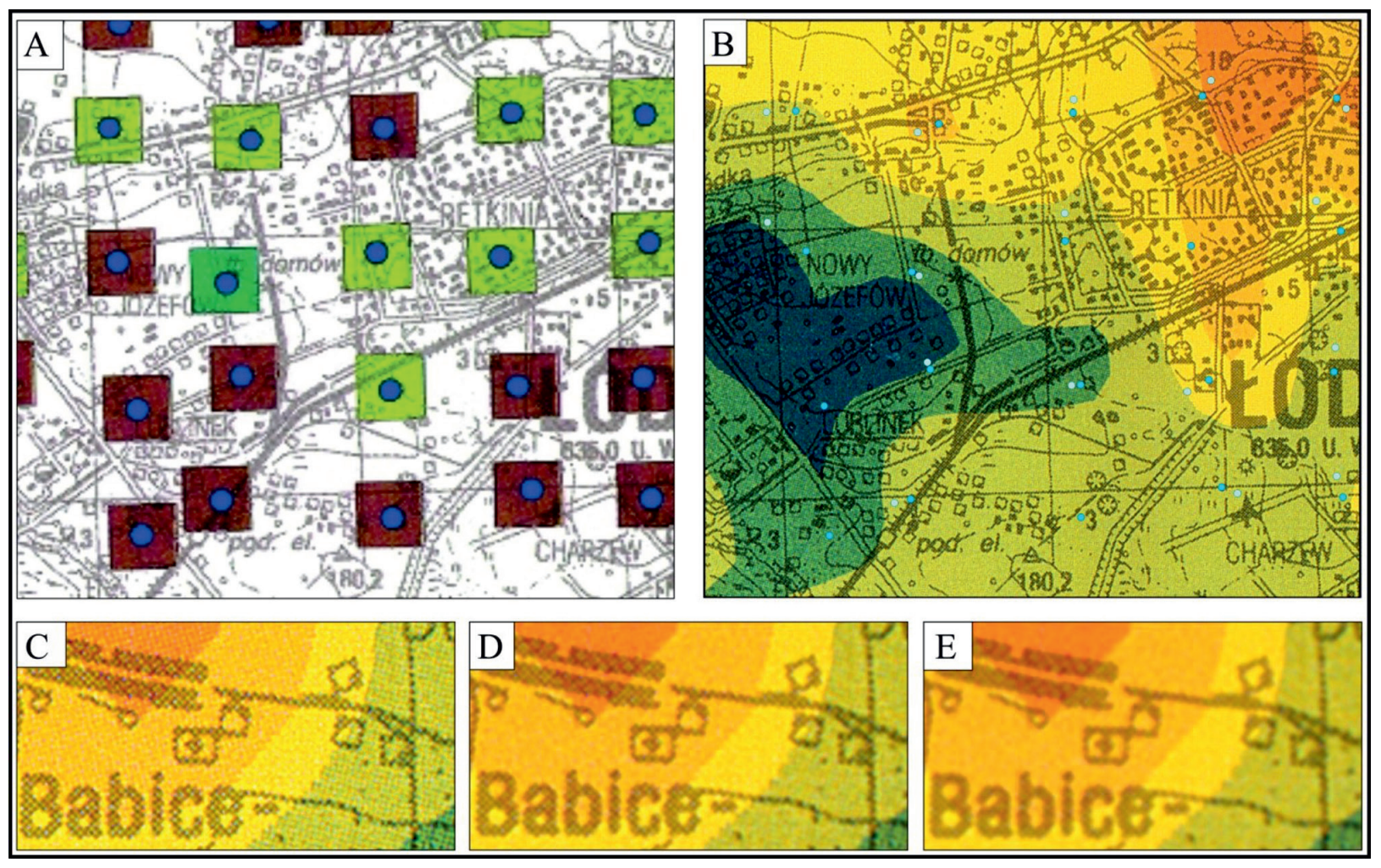

Ryc. 1. Pozyskiwanie i przetwarzanie danych źródłowych (opr. własne)

A - nałożenie warstwy punktowej na środek kwadratów opisujących pole badawcze

B - przesunięcie punktów, ciemnych do jasnych (kropki w odcieniach niebieskich)

C - obraz bez filtracji

D - obraz z filtrem

E - obraz z podwójnym filtrem

Fig. 1. Acquisition and processing of source data (own compilation)

$A-$ applying of a point layer to the center of the squares describing the study plot

$B$ - shifting points, dark to light (dots in shades of blue)

C - image without filtration

$D$ - image with filter

E - double filter image

Po szczegółowej inspekcji, znakomita większość należy do tej klasy, w której powinna się znajdować. Występowały również punkty otrzymujące wartości znajdujące się pomiędzy przedziałami klas, co było spowodowane ich lokalizacją na skrajnych obszarach klas. Występowanie takich wartości uznano za prawidłowe ze względu na możliwość ich wystąpienia na skraju różnych interpolacji.

\section{Etap VIII. Interpolacja (Radial Basis Function)}

Założeniem metodyki było uzyskanie wyniku interpolacji jak najbardziej zbliżonych do tych na mapach prezentujących dane stężenia pierwiastków w glebie. Wykonanie interpolacji opierało się na przetestowaniu różnych metod i dostosowywaniu parametrów narzędzia dla uzyskania najbardziej zbliżonego wyniku do map pierwotnych. Do wykonania interpolacji zastosowano narzędzie do analizy geostatystycznej pozwalające na precyzyjny wybór parametrów interpolacji. Pomimo podania przez autorów oryginalnych map zastosowanej metody interpolacji, jaką była metoda odwrotnych odległości, to pomimo wykonania wielu wariantów (parametrów interpolacji), prace nie przyniosły tak dokładnych wyników jakich oczekiwano. Ostatecznie wykorzystano radialną funkcję bazową (Radial Basis Function) należącą do metod interpolacji dokładnej. Stosowana jest ona w przypadku dużych ilości danych nieróżniących się znacznie między sobą. Do wykonania interpolacji wykorzystano funkcję całkowicie uregulowanej krzywej (Completly Regularized Spline) odpowiedzialną za wygładzanie powierzchni z parametrem domyślnym. Opcje sąsiedztwa, które wyznaczają, jaki zakres danych bierze udział w interpolowaniu wartości, określono na 8 punktów ze względu na wyniki najbardziej zbliżone do źródłowych interpolacji.

Dane wyjściowe będące efektem wykonanych interpolacji były w postaci wektorowej. Dla celów późniejszych analiz niezbędną czynnością okazało się wyeksportowanie wyników interpolacji do warstw rastrowych. Model rastrowy przedstawia obraz za pomocą najmniejszych składowych obrazu, czyli pikseli, które rozłożone są równomiernie w postaci sieci.

\section{Etap IX. Zastosowanie metody rozmytej przynależności (Fuzzy membership)}

Wykorzystanie tej metody zakładało utworzenie dwóch warstw składających się z rastrowych interpolacji pierwiastków podzielonych na pozytywne oraz negatywne. Warstwa negatywna miała przedstawiać metale ciężkie 


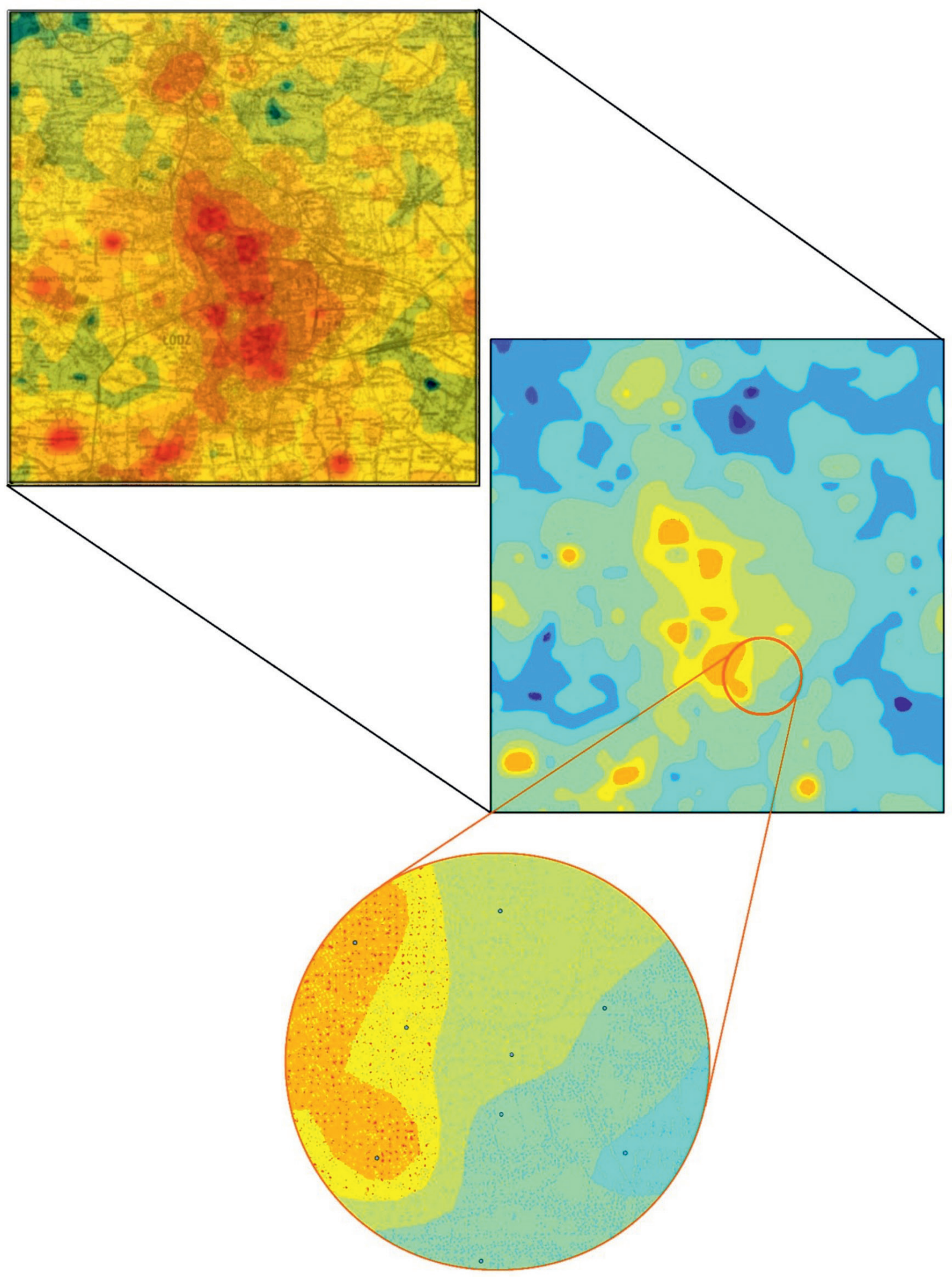

Ryc. 2. Klasyfikacja nadzorowana mapy stężeń wapnia (opr. własne)

Fig. 2. Supervised classification of calcium concentration maps (own compilation) 
uwzględnione w analizie, tj. cynk, nikiel, ołów, chrom, rtęć. Natomiast warstwa pozytywna zawierała pierwiastki wpływające korzystnie na środowisko glebowe. Były to węgiel organiczny, fosfor, wapń, magnez, siarka. Do wykonania powyższych założeń wykorzystano narzędzie stosujące logikę rozmytą. W tym modelu ustalane są wartości 0 oraz 1 na podstawie pierwotnych wartości dla danych znajdujących się na dodawanym obrazie. Wartości 0 oznaczają wartości nieprawdziwe dla wybranego zakresu, natomiast wartości 1 są prawdziwe. Dodatkowo, wartości znajdujące się pomiędzy zostają „rozmyte” z ukierunkowaniem na bliskość do rangi 0 lub 1. W przypadku pierwiastków negatywnych, każda z interpolacji uzyskała wartości 1 dla najwyższych stężeń metali oraz 0 dla stężeń najniższych. Dla wartości pozytywnych metodyka była identyczna - wysokie stężenia uzyskały wartość 1 , a najniższe wartość 0 .

Narzędzie rozmytej przynależności (Fuzzy membership) pozwala na wybór typu stosowanej techniki rozmytej (Bielska, Jaroszewicz 2012). Na potrzeby pracy wybrano metodę MSLarge. Typ ten wylicza wartości przynależności na podstawie średniej arytmetycznej oraz odchylenia standardowego, klasyfikuje wartości najwyższe jako 1 , a najniższe jako 0 .

Etap X. Zastosowanie rozmytego nakładania (Fuzzy Overlay) Utworzone warstwy rozmytej przynależności dla każdego pierwiastka zostały nałożone na siebie (ryc. 3). Było to 5 warstw dla wartości pozytywnych oraz 5 warstw dla wartości negatywnych. Pozwoliło to na utworzenie 2 map przedstawiających zsumowane pola obrazu dla wartości najwyższych. Wykorzystano rozmyte nakładanie z typem (OR) pozwalającym na połączenie wartości najwyższych $z$ różnych warstw rastrowych, w efekcie czego uzyskano obrazy, w których wysokie wartości nakładały się bądź tworzyły nowy obszar o wysokich wartościach występując $w$ danym miejscu jako jedyne. W przypadku obu map negatywnej oraz pozytywnej zawartości pierwiastków wykorzystano takie samo rozwiązanie metodyczne.

\section{Etap XI. Obliczenia na rastrach (kalkulator rastrów)}

Ostatnim etapem analizy było wyznaczenie obszarów najbardziej korzystnych pod względem najmniejszej zawartości metali ciężkich oraz najwyższych parametrach wpływających na żyzność gleby. W tym celu wykorzystano kalkulator rastrów pozwalający na wybranie konkretnych wartości bądź ich zakresów zawartych w rastrze. Zasada działania oparta jest o wyrażenia matematyczne pozwalające na wykonanie podstawowych obliczeń oraz wybieranie przedziałów, a także ich łączenie.

Dla uzyskania ostatecznych danych dotyczących obszarów korzystnych glebowo, z legend kolejnych map źródłowych wybrano odpowiednie zakresy. Dla metali ciężkich były to przedziały o najniższych wartościach, a dla pozytywnych pierwiastków i węgla organicznego były to wartości najwyższe (tab. 2). Podobnie uczyniono z najwyższymi zawartościami analizowanych metali ciężkich i wskazano obszary glebowo niekorzystne na podstawie odczytów z odpowiednich legend pod mapami. Odczyty zebrano w tabeli 1 . Utworzone na ich podstawie warstwy (ryc. 4) wyznaczają obszary najbardziej korzystne glebowo oraz te o najwyższych stężeniach metali ciężkich uznane za niekorzystne.
Tabela 1. Wyznaczone zakresy stężeń pierwiastków chemicznych na warstwie o wysokich stężeniach wybranych metali ciężkich

Table 1. Determined ranges of concentrations of chemical elements on the layer with high concentrations of selected heavy metals

\begin{tabular}{cc}
\hline Pierwiastek chemiczny & Zakres [ppm] \\
\hline Chrom Cr & $6-19$ \\
\hline Nikiel $\mathrm{Ni}$ & $5-12$ \\
\hline Ołów $\mathrm{Pb}$ & $25-66$ \\
\hline Cynk Zn & $70-222$ \\
\hline Rtęć Hg & $0,11-0,28$ \\
\hline
\end{tabular}

Źródło/Source: opr. własne/own compilation.

Tabela 2. Wyznaczone zakresy stężeń pierwiastków chemicznych na warstwie o niskich stężeniach wybranych metali ciężkich oraz wysokich stężeniach siarki, wapnia, fosforu, magnezu i węgla organicznego

Table 2. Determined ranges of chemical elements concentrations on the layer of low concentration of selected heavy metals and high concentrations of sulfur, calcium, phosphorus, magnesium and organic carbon

\begin{tabular}{cc}
\hline Pierwiastek chemiczny & Zakres [ppm] \\
\hline Chrom Cr & $1-4$ \\
\hline Nikiel Ni & $1-4$ \\
\hline Ołów Pb & $7-15$ \\
\hline Cynk Zn & $12-35$ \\
\hline Rtęć Hg & $0,05-0,07$ \\
\hline Pierwiastek chemiczny & Zakres [\%] \\
\hline Siarka S & $0,014-0,033$ \\
\hline Wapń Ca & $0,45-1,75$ \\
\hline Fosfor P & $0,055-0,092$ \\
\hline Magnez Mg & $0,08-0,20$ \\
\hline Węgiel organiczny Corg. & $2,77-5,8$ \\
\hline
\end{tabular}

Źródło/Source: opr. własne/own compilation.

\section{Analiza wyników badań}

Uzyskane warstwy rastrowe wyznaczające obszary o najwyższych stężeniach metali ciężkich oraz o najniższych stężeniach metali ciężkich i zarazem najwyższych wartościach mających korzystny wpływ na środowisko glebowe, tworzą informacje przestrzenną, która może pozwolić na wybór danego fragmentu obszaru do sprecyzowanej działalności lub konkretnego przeznaczenia. Mogą to być np. tereny użytkowane rolniczo o odpowiednio ograniczonych parametrach pierwiastków chemicznych, tereny pod zalesienie w celu zatrzymania lub ograniczenia migracji zanieczyszczeń. Mogą zostać wskazane obszary do wyłączenia z jakiegokolwiek użytkowania ze względu na istniejące skażenie gleb i zagrożenie dla zdrowia człowieka oraz innych organizmów roślinnych i zwierzęcych.

Oparcie analizy o takie wyniki nie jest kompletne i wymaga poparcia konkretnymi danymi. Ze względu na charakter ich przeznaczenia, dane takie mogą stanowić pewnego rodzaju tło dla innych zastosowań lub mieć charakter poglądowy. W niniejszej analizie zostaną wykorzystane dane o wysokości bezwzględnej, pokryciu terenu, potencjalnych punktowych ogniskach zanieczyszczeń, infrastrukturze drogowej, co pozwoli na znalezienie prawdopodobnych zależności pomiędzy tymi czynnikami oraz parametrami gleb. 


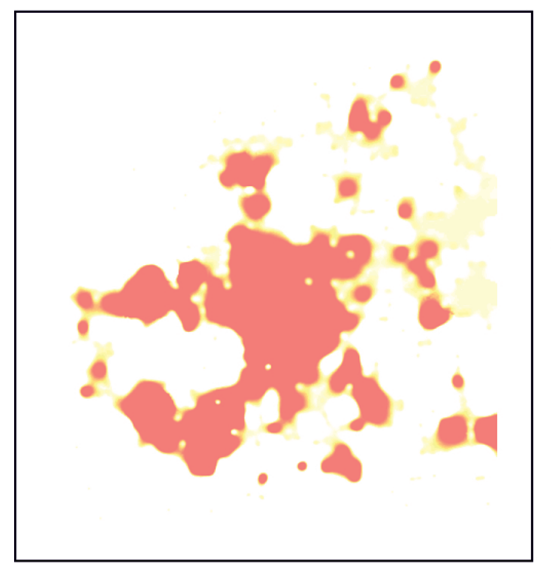

\section{Magnez}
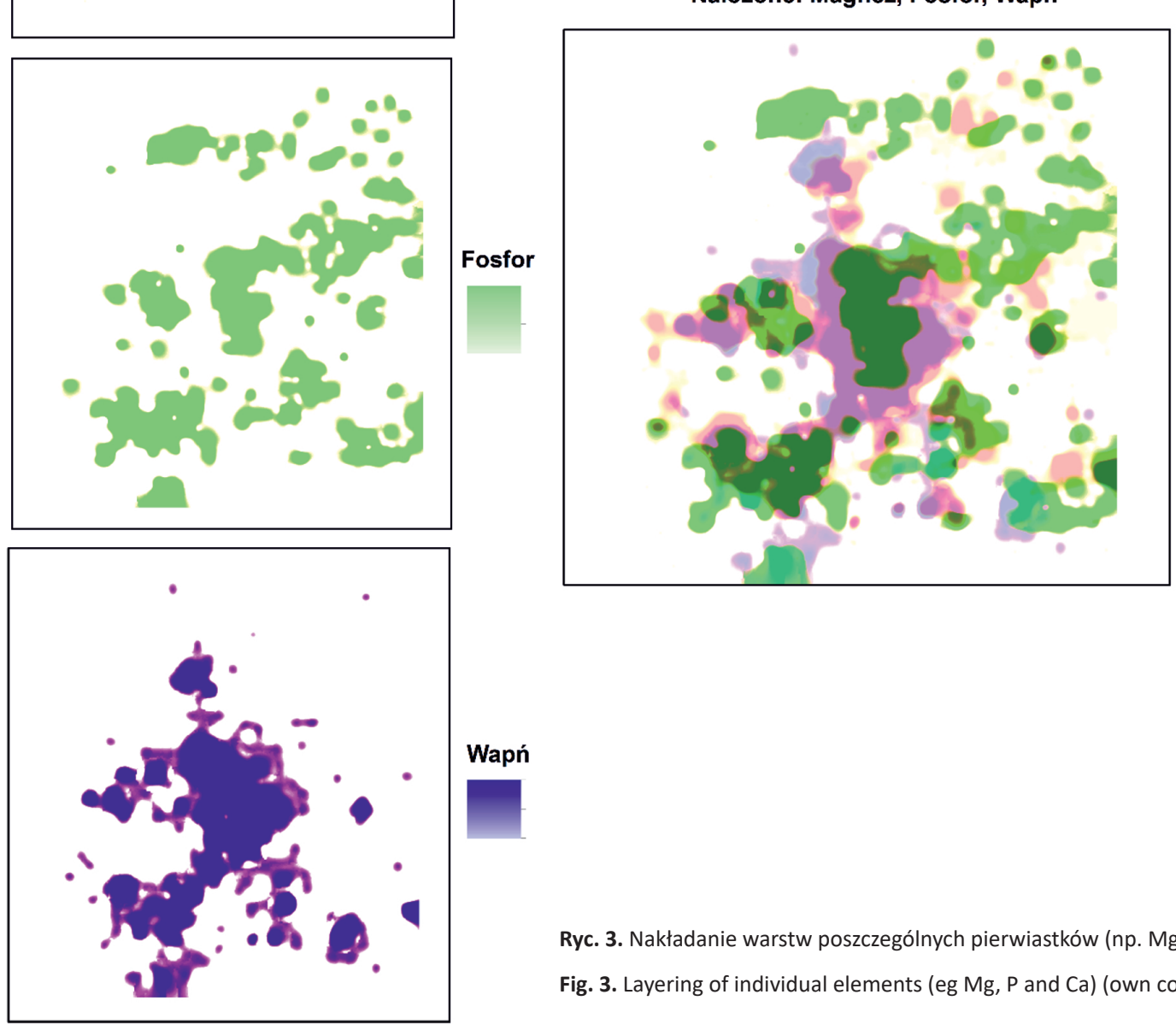

\section{Wapń}

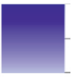

Ryc. 3. Nakładanie warstw poszczególnych pierwiastków (np. Mg, P i Ca) (opr. własne)

Fig. 3. Layering of individual elements (eg Mg, $\mathrm{P}$ and $\mathrm{Ca}$ ) (own compilation)

Tabela 3. Graniczne zawartości metali ciężkich kwalifikujące glebę do wyłączenia z użytkowania

Table 3. Limits of heavy metals content qualifying the soil to be excluded from use

\begin{tabular}{cc}
\hline Metal & Zawartość [ppm] \\
\hline Chrom Cr & 100 \\
\hline Nikiel Ni & 50 \\
\hline Ołów Pb & 70 \\
\hline Cynk Zn & 150 \\
\hline Rtęć Hg & 30 \\
\hline
\end{tabular}

Źródło: opr. na podstawie Kabata-Pendias i in. 1995; Kowalski i in. 2005.

Source: elaboration based on Kabata-Pendias at al. 1995; Kowalski at al. 2005.
Tabela 4. Zawartości średnie oraz maksymalne metali ciężkich w glebach według gatunku gleb

Table 4. Medium and maximum contents of heavy metals in soils according to soil type

\begin{tabular}{lccccc}
\hline \multirow{2}{*}{$\begin{array}{c}\text { Gatunek } \\
\text { gleby }\end{array}$} & \multicolumn{5}{c}{ Zawartość metalu [ppm] } \\
\cline { 2 - 6 } & Ołów Pb & Cynk Zn & Nikiel Ni & Chrom Cr & Rtęć Hg \\
\hline $\begin{array}{l}\text { Gleby bar- } \\
\text { dzo lekkie }\end{array}$ & $11,0-22,3$ & $26-59$ & $3,7-9,6$ & $8-20$ & $0,05-0,30$ \\
\hline $\begin{array}{l}\text { Gleby } \\
\text { lekkie }\end{array}$ & $13,0-24,5$ & $31-65$ & $5,9-13,0$ & $11-27$ & $0,08-0,70$ \\
\hline
\end{tabular}

Źródło: opr. na podstawie Kabata-Pendias i in. 1995; Kowalski i in. 2005. Source: elaboration based on Kabata-Pendias at al. 1995; Kowalski at al. 2005. 


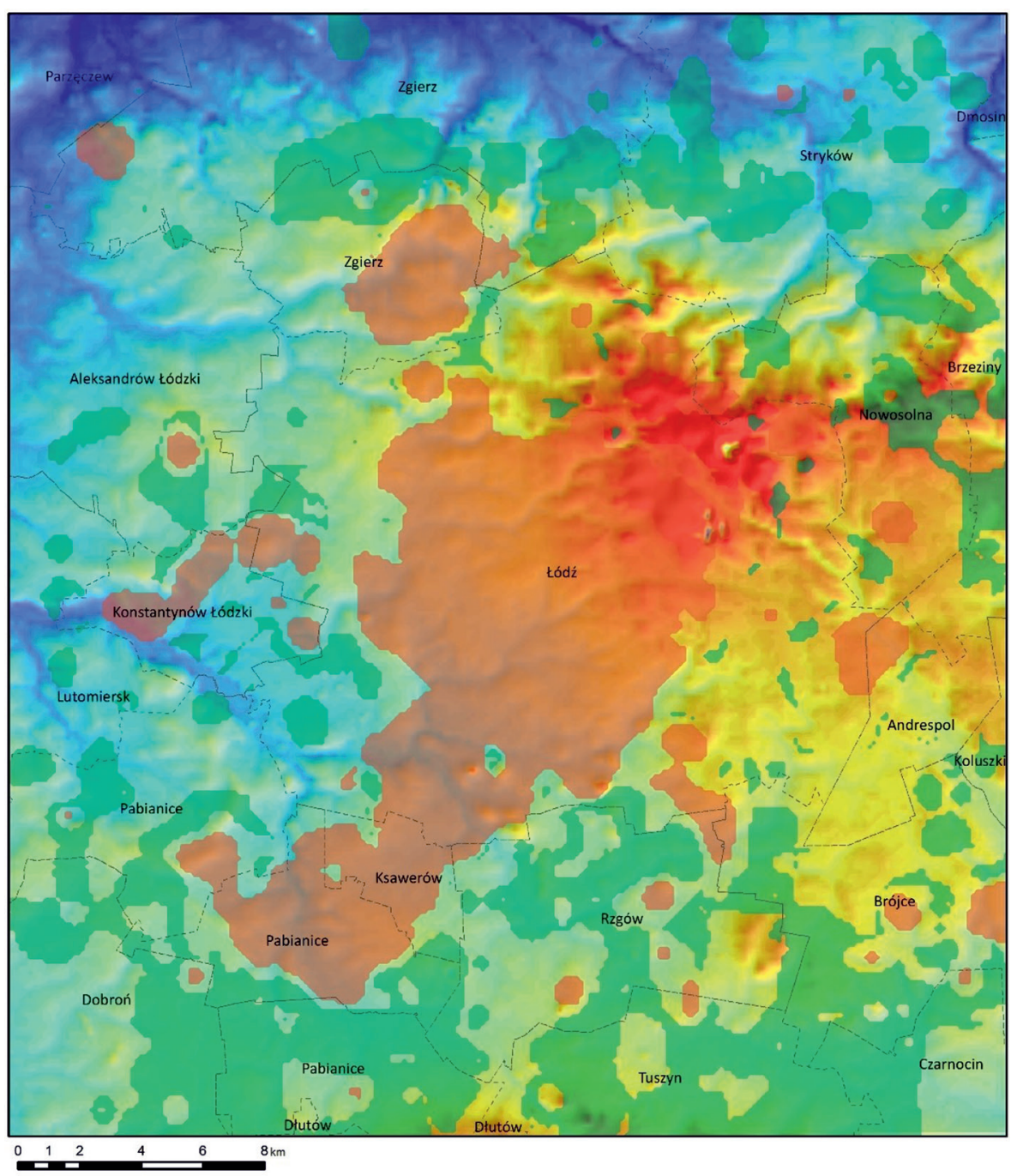

Obszary o najwyższych stężeniach [ $\mathrm{Zn}, \mathrm{Pb}, \mathrm{Hg}, \mathrm{Ni}, \mathrm{Cr}]$

Obszary o najniższych stężeniach [Zn, Pb, Hg, Ni, Cr] i najwyższych stężeniach [Corg, P, Ca, Mg, S]

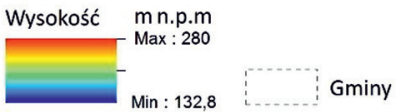

Ryc. 4. Obszary o korzystnych i niekorzystnych parametrach gleb w aglomeracji łódzkiej na tle wysokości n.p.m. (opr. własne)

Fig. 4. Areas of favorable and unfavorable soil parameters in the agglomeration of Łódź on the background of the altitude above the sea-level (own compilation)

Analizując chemizm gleb warto zwrócić uwagę na fakt, że metale ciężkie, jak: chrom, nikiel, ołów, rtęć, cynk w środowisku glebowym praktycznie nie występują naturalnie i głównie są związane z działalnością człowieka. Ich obecność w glebie jest wysoce niepożądana ze względu na ich negatywny wpływ na parametry chemiczne gleb, ale także na organizmy w nich bytujące. Należy też pamiętać o negatywnym pośrednim wpływie na pobliskie ekosystemy. Zwracając uwage na wybrane korzystne parametry gleb, nie będą one porównywane do stężeń granicznych. Występowanie tych pierwiastków w glebie, nawet w podwyższonych ilościach, nie prowadzi do degradacji gleby. Mimo iż wpływają one na roślinność ingerując $w$ ich kondycję i funkcjonowanie, to ich obecność nie jest czynnikiem prowadzącym do skażenia gleby i wyłączenia jej z użytkowania.
Warstwa negatywna o wysokich zakresach zawartości wybranych metali ciężkich

Porównując wybrane $\mathrm{w}$ analizie zakresy wartości dla chromu Cr 6-19 [ppm], które są wartościami z grupy najwyższych w badanym obszarze zabudowanym, można stwierdzić, że nie wykraczają one poza przedziały wartości naturalnych dla gleb zarówno bardzo lekkich, jak i lekkich, których jest znacząca przewaga w obrębie aglomeracji łódzkiej. Zawartości niklu Ni 5-12 [ppm] również są w zakresie wartości naturalnych, nieznacznie przekraczając je w przypadku gleb bardzo lekkich, których wartość graniczna wynosi 9,6 [ppm]. W przypadku zawartości ołowiu Pb 25-66 [ppm], zakresy wartości znacznie przekraczają wartości graniczne, bez względu na rodzaj gleby do 22,3 [ppm] dla gleb bardzo lekkich oraz 24,5 [ppm] dla gleb lekkich. Zwracając uwagę na wartości 
wykluczające glebę z użytkowania, która dla $\mathrm{Pb}$ wynosi 70 [ppm], można stwierdzić istotne zagrożenie wynikające z zanieczyszczenia gleb tym składnikiem. Kolejny pierwiastek chemiczny to cynk Zn 70-222 [ppm]. Stężenia tego pierwiastka są bardzo wysokie, znacząco przewyższają one minimalną wartość średnią występującą naturalnie w glebach, dla gleb bardzo lekkich 59 [ppm] oraz 65 [ppm] dla gleb lekkich. Wartości dopuszczalne 150 [ppm] są znacznie przekroczone. Ilości rtęci Hg w glebach aglomeracji łódzkiej zawierają się w przedziale 0,11-0,28 [ppm]. Mieszczą się one w wartościach naturalnych do 0,30 [ppm] dla gleb bardzo lekkich i do 0,70 [ppm] dla gleb lekkich.

Warstwa pozytywna o najniższych zakresach zawartości wybranych metali ciężkich

W przypadku tej warstwy wszystkie zakresy metali ciężkich mieszczą się w akceptowalnych przedziałach wartości, oscylując w większości w granicach średniej i nie przekraczając wartości maksymalnych.

Porównanie map rozkładu stężeń pierwiastków z modelem wysokościowym może pomóc w określeniu zależności pomiędzy występowaniem obszarów o podwyższonej akumulacji pewnych substancji chemicznych a ich pozycją morfometryczną w terenie. Tereny wyżej położone są bardziej wyeksponowane między innymi na działanie promieniowania słonecznego, co bezpośrednio wpływa na fazę ciekłą gleby i zróżnicowanie w występowaniu danych substancji chemicznych oraz ich akumulacji (Huanyao i in. 2016). Gleby o niskiej wilgotności bardziej narażone są na erozję, co jest również intensyfikowane przez występowanie stromych stoków i zachodzących przy odpowiednich warunkach procesach stokowych. Analizy przestrzenne parametrów chemicznych gleb wykazują zachodzące przemieszczanie się składników w dół stoku i ich akumulację na niższych poziomach (Huanyao i in. 2016).

Powyższa mapa (ryc. 4) z nałożonymi warstwami parametrów pozytywnych oraz negatywnych na wysokość n.p.m. nie wykazuje wyraźnych zależności stężeń danych pierwiastków z rzeźbą terenu, co może być podyktowane niewielką różnicą wysokości w obrębie aglomeracji łódzkiej. W centralnej części obszaru badań występuje Park Krajobrazowy Wzniesień Łódzkich. Mimo że reprezentuje on najwyższe wysokości bezwzględne na tym obszarze, to zawiera obszary zarówno o najwyższych i najniższych stężeniach metali ciężkich. W przypadku najniższych wysokości w rejonie Konstantynowa Łódzkiego, stwierdzono również brak zależności pomiędzy zróżnicowaniem stężeń metali oraz pozytywnych parametrów gleb. Nie stwierdzono relacji pomiędzy dużym zróżnicowaniem zawartości omawianych pierwiastków a stopniem urozmaicenia rzeźby terenu.

Poniżej przedstawiono ogniska zanieczyszczeń (niektóre już nieistniejące) wyznaczone przez J. Lisa i A. Pasieczną w 1989 roku w Atlasie Geochemicznym Aglomeracji Łódzkiej. Były to składowiska odpadów komunalnych: Zgierz, Łaskowice Łódź, Smolice Stryków, Nowosolna Łódź, Lublinek Łódź, Kalinko gmina Rzgów. Były to również składowiska odpadów przemysłowych: Boruta S.A. Zgierz, składowisko osadów ściekowych Zgierz, włókien chemicznych „Chemitex-Anilana” w Pałczewie gmina Brójce, odpadów paleniskowych zakładów Energetyki cieplnej w Łodzi w Gospodarzu, odpadów Fabryki Kwasu Cytrynowego „Cy- trokwas" w Zgierzu i osadów ściekowych Głównej Oczyszczalni Ścieków w Łodzi. Należy wymienić również ówczesnych producentów ścieków przemysłowych: Zakłady Jedwabnicze „Pierwsza” wŁodzi, PabianickieZakłady Farmaceutyczne „Polfa”, Zakłady Przemysłu Bawełnianego „Alba” w Łodzi, Przedsiębiorstwo usługowe „Koltex" w Łodzi, PKP Olechów w Łodzi, Zakłady Chemiczne „Argon” w Strykowie, Łódzka Spółdzielnia Mleczarska w Kraszewie.

Gleby obszarów graniczących z ciągami komunikacyjnymi są jednymi z najbardziej zanieczyszczonych. Szczególnie silnie zaznacza się to w kontekście zawartości metali ciężkich, których występowanie jest determinowane m.in. przez ilość poruszających się po drogach pojazdów, występowaniem roślinności przydrożnej oraz rodzajem gruntu (Laskowski i in. 2001). Badania wykazują, że gleby w sąsiedztwie dróg należą do najbardziej zanieczyszczonych, szczególnie metalami ciężkimi oraz solami stosowanymi do odladzania dróg (Tołoczko i in. 2009). Podwyższone stężenia metali mogą występować nawet w odległości do $50 \mathrm{~m}$ od osi jezdni (Czarnowska i in. 2002).

Na poniższej mapie (ryc. 5) dla potrzeb analizy zostały wyznaczone obszary o największym zagęszczeniu dróg, co powinno ułatwić znalezienie zależności pomiędzy występowaniem dróg a ilością metali ciężkich w glebach. Mapa zawiera również informacje o punktowych ogniskach zanieczyszczeń, jak składowiska odpadów, zakłady przemysłowe, miejsca odprowadzania ścieków przemysłowych. Dodatkowa warstwa cieków w obrębie aglomeracji ma na celu wyodrębnienie gleb w pobliżu dróg, przy których zanieczyszczenia mogą być łatwiej odprowadzane.

Analizowany obraz pozwala zauważyć korelację pomiędzy obszarami o wysokich wartościach parametrów negatywnych z obszarami o wysokim zagęszczeniu dróg. Podobna zależność dotyczy omawianych ognisk zanieczyszczeń. Warstwa reprezentująca tereny o najniższych zawartościach metali ciężkich zdecydowanie znajduje się poza obrębem zarówno punktowych ognisk zanieczyszczeń, a także obszarów o największym zagęszczeniu dróg. W przypadku obszarów w obrębie centrum gmin Stryków oraz Andrespol, pomimo występowania punktowych ognisk zanieczyszczeń, jak i gęstej sieci drogowej, brak jest występowania wysokich stężeń metali ciężkich, co może być związane z gęstością sieci rzecznej czy udziału powierzchni naturalnych. Obszar okolic Strykowa jest użytkowany rolniczo i słabo zurbanizowany. To zdecydowanie ogranicza dopływ zanieczyszczeń do tych gleb. Możliwe, że wysoka kultura rolna tego obszaru i duża produkcyjność tych gleb sprzyja ich oczyszczaniu z zanieczyszczeń.

Porównanie mapy użytkowania terenu (ryc. 6) z obszarami o cechach negatywnych i pozytywnych pod względem zawartości omawianych pierwiastków (ryc. 5) ma na celu określenie zależności pomiędzy rodzajami użytkowania terenu a zawartością metali ciężkich oraz zasobnością w pożądane składniki gleby.

Tabela 5 prezentuje udział poszczególnych klas użytkowania terenów ogółem jako: powierzchnia łączna w hektarach oraz ich procentowy udział w obrębie obszaru badań. Największa powierzchnia przypada na grunty orne, poza zasięgiem urządzeń nawadniających $(41,82 \%)$, co stanowi prawie połowę terenów. Zaznaczają się one $w$ pobliżu granic zabudowy $w$ kierunku zewnętrznym aglomeracji zmniejszając udział przy 

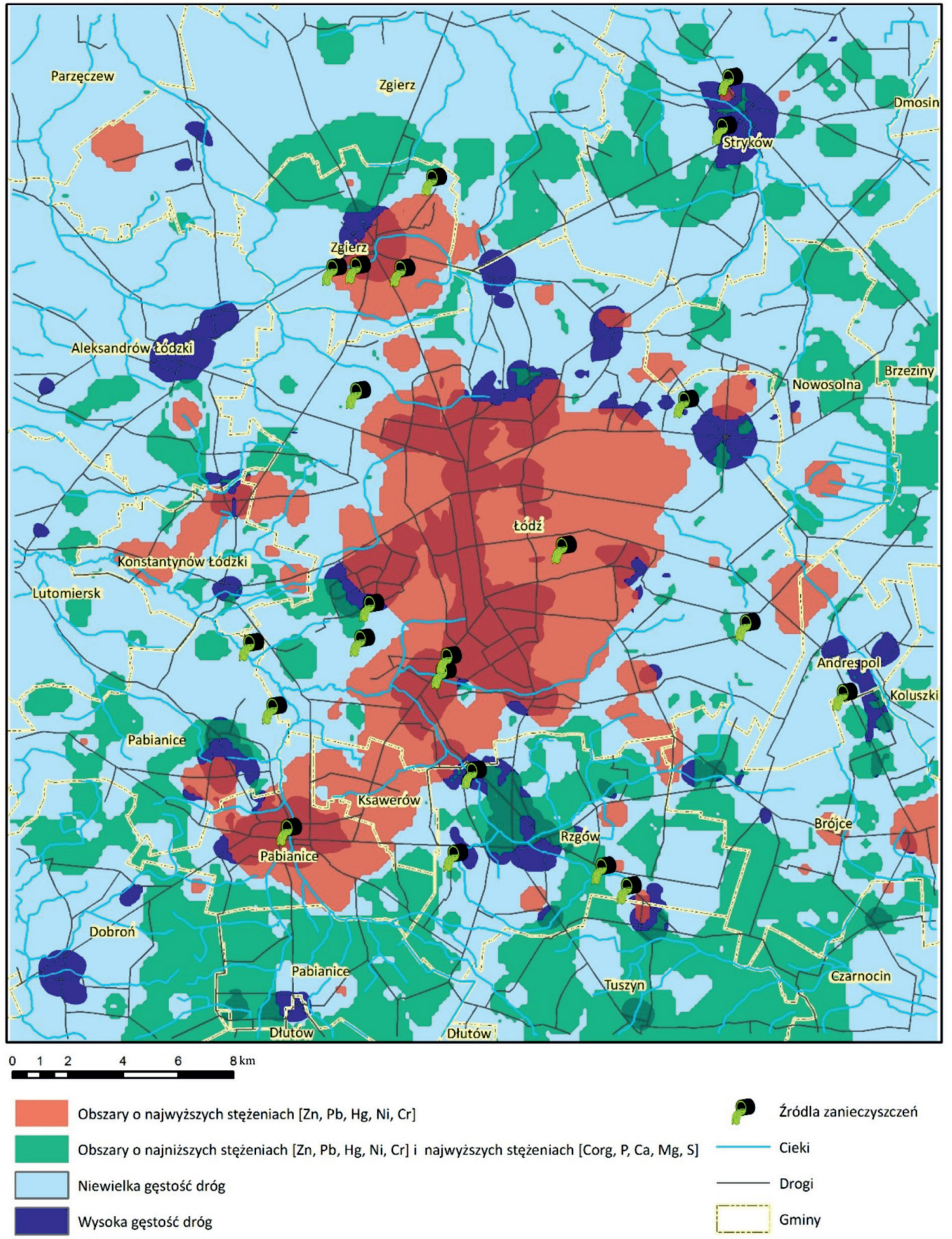

Ryc. 5. Wyznaczone obszary pozytywne oraz negatywne na tle gęstości dróg wraz z potencjalnymi ogniskami zanieczyszczeń (opr. własne)

Fig. 5. Defined positive and negative areas on the background of road density with potential pollutants (own compilation)

najbardziej odległych obszarach aglomeracji, oddając część udziału powierzchniom naturalnym, takim jak: lasy mieszane $(7,58 \%)$, lasy iglaste $(6,16 \%)$ i lasy liściaste (3,48\%). Tereny o luźnej zabudowie miejskiej (12,33\%) uwydatniają się w centralnej części mapy i należą w większości do miasta Łodzi, ale i mniejszych miejscowości, jak: Zgierz, Andrespol, Pabianice, Ksawerów, Konstantynów Łódzki oraz Aleksandrów Łódzki. Największą ilość powierzchni o innym użytkowaniu w obrębie zabudowań stanowią złożone systemy upraw i działek (11,38\%), występujące nawet w centralnej części miasta Łodzi. Istotną część powierzchni zajmują również obszary charakteryzowane jako tereny zajęte głównie przez rolnictwo z dużym udziałem roślinności naturalnej (7,36\%) o silnym rozczłonkowaniu występującym na większości obszaru aglomeracji łódzkiej. Udział pozostałych powierzchni jest znikomy i wynosi często poniżej 1\% (tab. 5). 

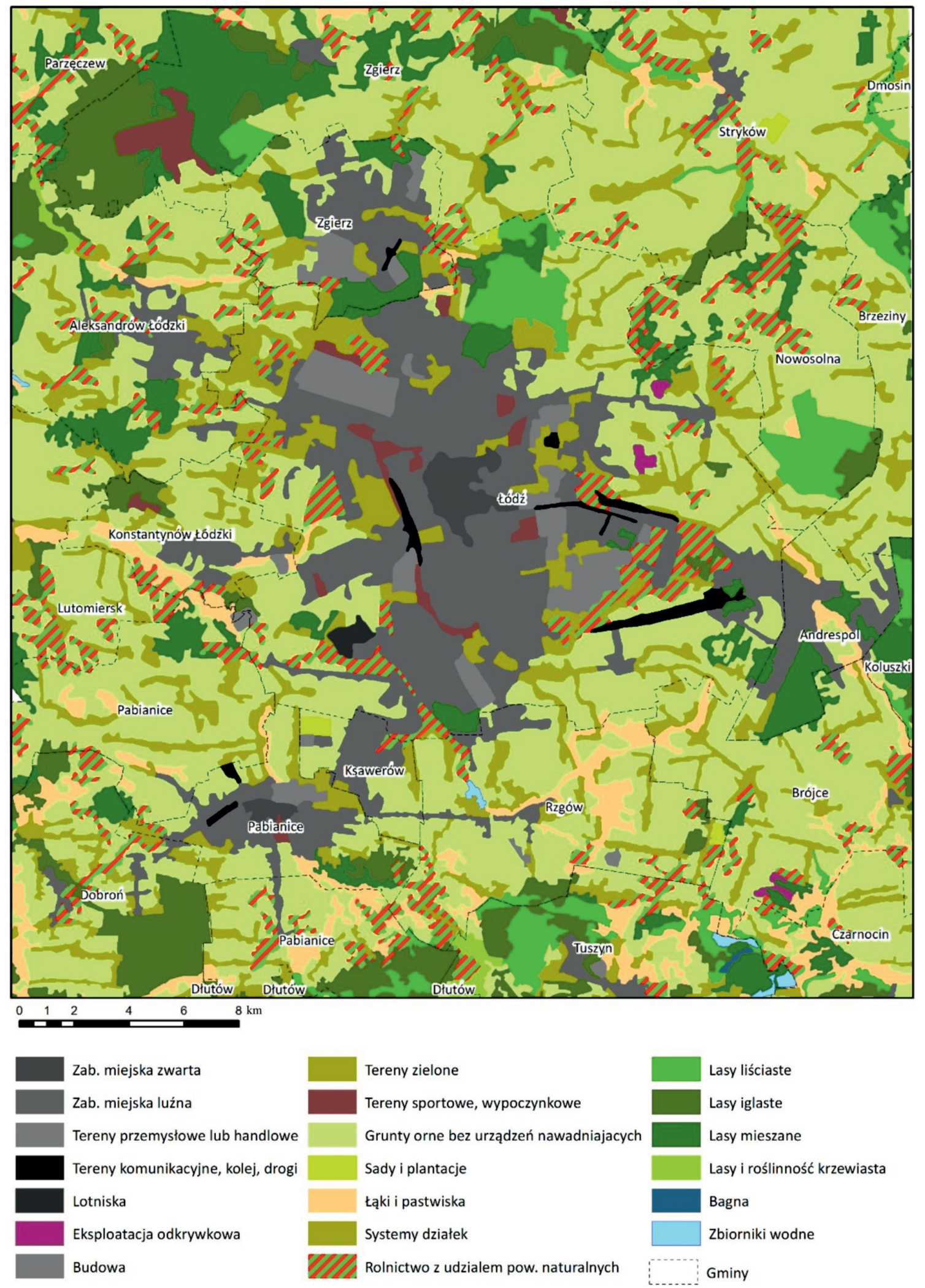

Ryc. 6. Użytkowanie terenu w aglomeracji łódzkiej (opr. własne)

Fig. 6. Land use in the Łódź agglomeration (own compilation)

Nałożenie wyznaczonych warstw pozytywnej oraz negatywnej pod względem parametrów glebowych na mapę użytkowania terenu pozwoliło na wyznaczenie wspomnianych już zależności między sposobem użytkowania terenu a wysoką/niską zawartością wybranych pierwiastków. Zarówno tabela 6, jak i tabela 7 prezentują udziały powierzchniowe w hektarach oraz procentowe w obrębie warstw obszarów o cechach pozytywnych i negatywnych. 
Tabela 5. Powierzchnia oraz procentowy jej udział danej klasy użytkowania terenu

Table 5. Area and percentage of its share of a given land use classes

\begin{tabular}{|c|c|c|}
\hline Klasa użytkowania terenu & Powierzchnia łączna [ha] & Użytkowanie [\%] \\
\hline Budowy & 25,4 & 0,02 \\
\hline Bagna śródlądowe & 28,4 & 0,02 \\
\hline Lotniska & 137,2 & 0,11 \\
\hline Miejsca eksploatacji odkrywkowej & 138,8 & 0,11 \\
\hline Zbiorniki wodne & 146,6 & 0,12 \\
\hline Sady i plantacje & 212,9 & 0,17 \\
\hline Lasy i roślinność krzewiasta w stanie zmian & 307,4 & 0,25 \\
\hline Tereny komunikacyjne i związane z komunikacją drogową i kolejową & 577,7 & 0,47 \\
\hline Zabudowa miejska zwarta & 701,7 & 0,57 \\
\hline Tereny sportowe i wypoczynkowe & 1158,0 & 0,94 \\
\hline Tereny zielone & 1293,8 & 1,05 \\
\hline Tereny przemysłowe lub handlowe & 2383,0 & 1,93 \\
\hline Lasy liściaste & 4291,5 & 3,48 \\
\hline Łąki i pastwiska & 5058,8 & 4,11 \\
\hline Lasy iglaste & 7584,4 & 6,16 \\
\hline Tereny zajęte głównie przez rolnictwo z dużym udziałem roślinności naturalnej & 9064,9 & 7,36 \\
\hline Lasy mieszane & 9339,2 & 7,58 \\
\hline Złożone systemy upraw i działek & 14018,3 & 11,38 \\
\hline Zabudowa miejska luźna & 15188,4 & 12,33 \\
\hline Grunty orne poza zasięgiem urządzeń nawadniających & 51508,1 & 41,82 \\
\hline
\end{tabular}

Źródło: opr. na podstawie CLC 2000.

Source: elaboration based on CLC 2000.

Tabela 6. Powierzchnia oraz procentowy jej udział w poszczególnych klasach użytkowania terenu w obrębie warstwy reprezentującej pozytywne właściwości gleb

Table 6. Surface and its percentage share in particular classes of land use within the layer representing positive soil properties

\begin{tabular}{|c|c|c|}
\hline Klasa użytkowania terenu & Powierzchnia łączna [ha] & Użytkowanie [\%] \\
\hline Tereny zielone & 28,9 & 0,11 \\
\hline Bagna śródlądowe & 28,3 & 0,11 \\
\hline Sady i plantacje & 33,1 & 0,12 \\
\hline Miejsca eksploatacji odkrywkowej & 35,5 & 0,13 \\
\hline Lasy i roślinność krzewiasta w stanie zmian & 40,7 & 0,15 \\
\hline Lasy liściaste & 1350,1 & 5,04 \\
\hline Lasy mieszane & 1376,1 & 5,13 \\
\hline Tereny zajęte głównie przez rolnictwo z dużym udziałem roślinności naturalnej & 1940,8 & 7,24 \\
\hline Łąki i pastwiska & 2115,0 & 7,89 \\
\hline Lasy iglaste & 2578,3 & 9,62 \\
\hline Złożone systemy upraw i działek & 3504,1 & 13,07 \\
\hline Grunty orne poza zasięgiem urządzeń nawadniających & 13649,2 & 50,91 \\
\hline
\end{tabular}

Źródło: opr. na podstawie CLC 2000.

Source: elaboration based on CLC 2000. 
Tereny o wysokich stężeniach w glebie pierwiastków wpływających korzystnie oraz najniższych zawartościach metali ciężkich (tab. 6) odpowiadają gruntom ornym poza zasięgiem urządzeń nawadniających (50,91\%), będącym w największym udziale ogólnej powierzchni w aglomeracji łódzkiej. Kolejno, drugim największym udziałem (tab. 6) charakteryzują się złożone systemy upraw i działek (13,07\%) stanowiące 11,38\% (tab. 5) obszaru w aglomeracji i będące również silnie rozczłonkowanym rodzajem użytkowania terenu na obszarze badań. Następnie są lasy iglaste (9,62\%) będące 6,16\% w użytkowaniu ogólnym, łąki i pastwiska $(7,89 \%)$, czyli $4,11 \%$ w użytkowaniu ogólnym. Tereny zajęte głównie przez rolnictwo z dużym udziałem roślinności naturalnej (7,24\%), stanowią 7,36\% w użytkowaniu ogólnym, lasy mieszane $(5,13 \%)$ będące $7,58 \%$ w użytkowaniu ogólnym, lasy liściaste (5,04\%), czyli 3,48\% w użytkowaniu ogólnym. Pozostałe rodzaje użytkowania w granicy warstwy pozytywnej są wartościami poniżej $1 \%$.

Tabela 7. Powierzchnia oraz procentowy jej udział w poszczególnych klasach użytkowania terenu w obrębie warstwy reprezentującej negatywne właściwości gleb

Table 7. Surface and its percentage share in particular classes of land use within the layer representing the negative soil properties

\begin{tabular}{lcc}
\hline & Klasa użytkowania terenu & Użytkowanie [\%] \\
\hline Budowy & 7,5 & 0,04 \\
\hline Sady i plantacje & 54,8 & 0,26 \\
\hline Miejsca eksploatacji odkrywkowej & 55,4 & 0,27 \\
\hline Lotniska & 75,1 & 0,36 \\
\hline Lasy liściaste & 188,4 & 0,90 \\
\hline Tereny komunikacyjne i związane z komunikacją drogową i kolejową & 291,2 & 1,39 \\
\hline Lasy iglaste & 304,6 & 1,46 \\
\hline Lasy mieszane & 415,2 & 1,99 \\
\hline Łąki i pastwiska & 417,7 & 2,00 \\
\hline Tereny sportowe i wypoczynkowe & 2,22 \\
\hline Zabudowa miejska zwarta & 463,8 & 3,36 \\
\hline Tereny zajęte głównie przez rolnictwo z dużym udziałem roślinności naturalnej & 4,53 \\
\hline Tereny zielone & 701,7 & 5,32 \\
\hline Złożone systemy upraw i działek & 947,0 & 7,63 \\
\hline Tereny przemysłowe lub handlowe & 1112,4 & 8,19 \\
\hline Grunty orne poza zasięgiem urządzeń nawadniających & 1595,2 & 17,38 \\
\hline Zabudowa miejska luźna & 1710,8 & 42,70 \\
\hline Zódl: opr. na podstawie & 3633,0 & 8923,7 \\
\hline
\end{tabular}

Źródło: opr. na podstawie CLC 2000.

Source: elaboration based on CLC 2000.

W obrębie warstwy rastrowej o najwyższych stężeniach metali ciężkich (tab. 7), dominuje klasa - zabudowa miejska luźna $(42,70 \%)$, stanowiąca $12,33 \%$ w powierzchni ogólnej (tab. 5). Grunty orne poza zasięgiem urządzeń nawadniających stanowią 17,38\% (co przekłada się na $41,82 \%$ ogólnej powierzchni). Istotny jest fakt, iż dotyczą one obszarów położonych w sąsiedztwie zabudowy. Tereny przemysłowe lub handlowe $(8,19 \%)$ posiadają udział 1,93\% w użytkowaniu ogólnym. Złożone systemy upraw i działek (7,63\%) obejmują 11,38\% w powierzchni ogólnej. Występują one w centralnej części gminy Łódź, pomiędzy gęstą zabudową oraz na zewnętrznych jej krańcach. Tereny zielone (5,32\%) mają $1,05 \%$ w użytkowaniu ogólnym. Warto zauważyć, że tereny zielone w powierzchni ogólnej użytkowania terenu stanowią 1293,8 ha, natomiast w obszarze rastra jest to 1112,4 ha, czyli prawie cały obszar tego rodzaju użytkowania. Tereny zajęte głównie przez rolnictwo z dużym udziałem roślinności naturalnej $(4,53 \%)$ zawierają się w 7,36\% w użytkowaniu ogólnym. Zabudowa miejska zwarta 3,36\% odzwierciedla się 0,57\% w użytkowaniu ogólnym, co odpowiada $100 \%$ powierzchni tego użytkowania. Pozostałe klasy użytkowania mieszczą się w przedziałach poniżej $2 \%$.

\section{Podsumowanie}

W artykule wykorzystano informacje z atlasu geochemicznego aglomeracji łódzkiej, który został opublikowany w formie papierowej (Lis, Pasieczna 1998). Atlas ten przedstawia stężenia wybranych pierwiastków chemicznych w glebie. Informacje zawarte na mapach drukowanych w obrębie atlasu są przedstawione w formie warstw ciągłych interpolowanych z warstw punktowych.

Jednym z celów niniejszego opracowania była próba uzyskania danych wejściowych w postaci punktów poprzez ich digitalizację z analogowych map źródłowych. Szczególnie istotne było uzyskanie obrazu jak najbar- 
dziej zbliżonego do tego przedstawianego na materiałach pierwotnych. Do wykonania tego zadania najbardziej optymalne okazały się narzędzia GIS. Prowadzone prace można było wykonać na dwa sposoby. Pierwszy zakładał ręczną digitalizację każdej z map. Ze względu na pracochłonność, metoda ta została odrzucona. W związku z tym postanowiono zastosować metodę automatyczną interpretacji i digitalizacji treści map papierowych. Niestety, druk offsetowy powodował pewne trudności w całkowicie automatycznej interpretacji fotofonu. W toku analiz określono za najskuteczniejszą - metodę nadzorowaną.

Następnie uzyskane dane posłużyły do wykonania swego rodzaju bonitacji glebowej w formie przestrzennej ukazując obszary korzystne glebowo oraz te niekorzystne, analizując je przy wykorzystaniu danych o: zmiennych parametrach chemicznych gleb oraz różnego rodzaju warstw przestrzennych.

W obrębie aglomeracji łódzkiej w badaniach sprzed 20 lat widoczne są przekroczenia wartości dopuszczalnych metali ciężkich, w tym: ołowiu [Pb] oraz w znacznych ilościach cynku [Zn]. Na podstawie przeprowadzonej analizy można wnioskować, że w aglomeracji łódzkiej zanieczyszczenia metalami ciężkimi występują na całym obszarze zabudowy miejskiej zwartej oraz na terenach zieleni miejskiej, na większości terenów przemysłowych lub handlowych, ale także na połowie zabudowy miejskiej luźnej. Zanieczyszczenia metalami ciężkimi obejmują również swym zasięgiem grunty orne w pobliżu zabudowań. Występowanie zanieczyszczeń gleb metalami ciężkimi jest również zauważalne w obszarach o gęstej sieci drogowej oraz w pobliżu punktowych ognisk zanieczyszczeń, jak zakłady przemysłowe czy składowiska odpadów. Nie zauważono powiązań pomiędzy akumulacją metali ciężkich a względną wysokością na obszarze aglomeracji łódzkiej.

W przypadku najbardziej żyznych gleb w obrębie aglomeracji, obszary ich występowania przypadają w większości na grunty orne znajdujące się poza zasięgiem zabudowy oraz oddziaływania dróg. Niskimi zawartościami metali ciężkich oraz żyznością cechują się również obszary w klasie różnego rodzaju upraw oraz działek. W znakomitej większości tereny o pozytywnych cechach gleby związane są z zagospodarowaniem ich przez człowieka, lecz przypadają również na obszary naturalne, na których działalność antropogeniczna jest znikoma, jak: lasy iglaste (bory), liściaste, mieszane oraz łąki i pastwiska.

Wyniki analizy wykazały, że największe zanieczyszczenia gleb związane są z takimi typami użytkowania terenu, jak: obszary miast, powierzchnie, gdzie wykonywana jest działalność przemysłowa oraz występuje gęsta infrastruktura drogowa. W przypadku gleb o najlepszych parametrach w większości są to również obszary użytkowane rolniczo jako działki czy sady, a udział powierzchni naturalnych zaznacza się już w mniejszym stopniu.

\section{Literatura}

Bednářová, Z., Kalina, J., Hájek, O., Sáňka, M., Komprdová, K., 2016. Spatial distribution and risk assessment of metals in agricultural soils. Geoderma 284, 113-121. https://doi.org/10.1016/j.geoderma.2016.08.021.

Bielecka, E., 2006. Systemy informacji geograficznej. Teoria i zastosowania. Wydawnictwo PJWSTK, Warszawa, 1-229.
Bielecka, E., Maj, K., 2009. Systemy informacji przestrzennej. Podstawy teoretyczne. Wydawnictwo WAT, 1-204.

Bielska, A., Jaroszewicz, J., 2012. Przegląd metod wykorzystujących funkcje rozmyte i analizy wielokryterialne do opracowania cyfrowych map glebowo-rolniczych. Acta Sci. Pol. Geod. Descr. Terr. $11(2), 5-15$.

CLC 2000 - CORINE Land Cover

Cutillas-Barreiro, L., Pérez-Rodríguez, P., Gómez-Armesto, A., José Fernández-Sanjurjo, M., Álvarez-Rodríguez, E., Núñez-Delgado, A., Arias-Estévez, M., Nóvoa-Muñoz, J.C., 2016. Lithological and land-use based assessment of heavy metal pollution in soils surrounding a cement plant in SW Europe. Science of The Total Environment 562, 179-190. DOI: 10.1016/j.scitotenv.2016.03.198.

Czarnowska, K., 1996. Metale ciężkie w skałach macierzystych jako tło geochemiczne gleb. Roczniki Gleboznawcze 47 (supl.), 43-50. http://ssa.ptg.sggw.pl/files/artykuly/1996_47/1996_tom_47_suplement/tom_47_nr_suplement_43-50.pdf.

Czarnowska, K., 1997. Poziom niektórych metali ciężkich w glebach i liściach drzew miasta Łodzi. Roczniki Gleboznawcze 48 (3/4), 49-61. http://ssa.ptg.sggw.pl/files/artykuly/1997_48/1997_tom _48_nr_3-4/tom_48_nr_3-4_49-61.pdf.

Czarnowska, K., Chlibiuk, M., Kozanecka, T., 2002. Pierwiastki śladowe w glebach uprawnych przy drogach wokół Warszawy. Roczniki Gleboznawcze 53 (3/4), 67-74. http://ssa.ptg.sggw.pl/files/arty kuly/2002_53/2002_tom_53_nr_3-4/tom_53_nr_3-4_67-74.pdf.

Czarnowska, K., Walczak, J., 1988. Distribution of zinc, lead and magnanese in soils of Łódź City. Roczniki Gleboznawcze 39 (1), 19-27. http://ssa.ptg.sggw.pl/files/artykuly/1988_39/1988_tom_39_nr_1/ tom_39_nr_1_19-27.pdf.

Gaspéri, J., Ayrault, S., Moreau-Guigon, E., Alliot, F., Labadie, P., Budzinski, H., Blanchard, M., Muresan, B., Caupos, E., Cladière, M., Gateuille, D., Tassin, B., Bordier, L., Teil, M.J., Bourges, C., Desportes, A., Chevreuil, M., Moilleron, R. 2016. Contamination of soils by metals and organic micropollutants: case study of the Parisian conurbation. Environmental Science and Pollution Research, Springer Verlag, 1-15. DOI: 10.1007/s11356-016-8005-2.

Gorlach, E., Mazur, T., 2002. Chemia rolna. Wydawnictwo Naukowe PWN, Warszawa, 1-346.

Gotlib, D., Iwaniak, A., Olszewski, R., 2007. GIS. Obszary zastosowań. Wydawnictwo Naukowe PWN, Warszawa, 1-250.

Hao, L., Tian, M., Zhao, X., Zhao, Y., Lu, J., Bai, R., 2016. Spatial distribution and sources of trace elements in surface soils: Changchun, China Insights from stochastic models and geostatistical analyses. Geoderma 273, 54-63. DOI: 10.1016/j.geoderma.2016.03.017.

Huanyao, L., Jiaogen, Z., Qingyu, F., Yuyuan, L., Yong, L., Jinshui, W., 2016. Effects of land use and topography on spatial variety of soil organic carbon density in a hilly, subtropical catchment of China. Soil Research 55 (2), 134-144. https://doi.org/10.1071/SR15038.

Kabata-Pendias, A., Pendias, H., 1999. Biogeochemia pierwiastków śladowych. Wyd. 2 zmienione. Wydawnictwo Naukowe PWN, Warszawa, 1-398.

Kabata-Pendias, A., Piotrowska, M., Motowicka-Trelak, T., Maliszewska-Kordybach, B., Filipiak, K., Krakowiak, A., Pietruch, C., 1995. Podstawy oceny chemicznego zanieczyszczenia gleb. Metale ciężkie, siarka i WWA. PIOŚ, IUNG, Bibl. Monitoringu Środowiska, Warszawa, 1-34.

Kabata-Pendias, A., Szteke, B., 2012. Pierwiastki śladowe w geo- i biosferze. Instytut Uprawy Nawożenia i Gleboznawstwa - Państwowy Instytut Badawczy, Puławy, 1-270.

Kowalski, A., Niedzielski, P., Siepak, J., Boszke, L., 2005. Rtęć w środowisku przyrodniczym. Przegląd Komunalny 3, 18-19.

Laskowski, S., Tołoczko, W., 1995. Ocena stanu środowiska glebowego w otoczeniu aglomeracji miejsko-przemysłowej Zgierza. Zesz. Probl. Post. Nauk Roln. 418 (1), 313-320. https://www.resear chgate.net/publication/313902457.

Laskowski, S., Tołoczko, W., 1998. Zmiany odczynu i zawartości siarki w glebach objętych oddziaływaniem aglomeracji miejsko-przemysłowej Zgierza. Zesz. Probl. Post. Nauk Roln. 456, 343-351. https:// www.researchgate.net/publication/313842879.

Laskowski, S., Tołoczko, W., 2001. Alterations of some chemical and physico-chemical properties of selected soils in field ecosystems. Acta Agrophysica 50, 177-188. https://www.researchgate.net/ publication/313846513. 
Laskowski, S., Tołoczko, W., 2003. Zawartość benzo/a/pirenu, antracenu i fenentrenu w glebach przy drogach o różnym natężeniu ruchu. Zesz. Probl. Post. Nauk Roln. 493, 193-199. https://www.resear chgate.net/publication/314221431.

Laskowski, S., Tołoczko, W., Rólka, M., 2001. Zawartość Pb, Zn i Cu w glebach przy drogach o różnym natężeniu ruchu w okolicach Łodzi. Acta Agrophysica 56, 137-144. https://www.researchgate. net/publication/313853018.

Laskowski, S., Tołoczko, W., Trawczyńska, A., 2005a. Wpływ nawodnień na niektóre właściwości chemiczne mad bardzo lekkich doliny Neru. Inżynieria Ekologiczna 12, 205-206. https://www.resear chgate.net/publication/314232143.

Laskowski, S., Trawczyńska, A., Tołoczko, W., 2005b. Polycyclic aromatic hydrocarbons (PAH's) in arable soils in proximity of communication tracts near Lodz city. Ecol. Chem. and Eng. 12 (7), 709-715. https://www.researchgate.net/publication/313878359.

Laskowski, S., Trawczyńska, A., Tołoczko, W., 2006. Influence of irrigation on some chemical properties of very lightfan soils of the Ner Valley. Ecological Chemistry and Engineering 13 (1-2), 79-84. https://www.researchgate.net/publication/314235717.

Lis, J., Pasieczna, A., 1998. Atlas geochemiczny aglomeracji łódzkiej, Część 1: gleby, osady wodne, wody powierzchniowe. PIG, Warszawa.

Longley, P.A., Goodchild, M.F., Maguire, D.J., Rhind, D.W., 2006. GIS. Teoria i praktyka. Wydawnictwo Naukowe PWN, Warszawa, 1-519.

Lucisine, P., Lecerf, A., Danger, M., Felten, V., Aran, D., Auclerc, A.M., Gross, E., Huot, H., Morel, J.-L., Muller, S., Nahmani, J., Maunoury-Danger, F., 2015. Litter chemistry prevails over litter consumers in mediating effects of past steel industry activities on leaf litter decomposition. Science of The Total Environment 537, 213-224. DOI: 10.1016/j.scitotenv.2015.07.112.

Niedbała, M., Smolińska, B., Król, K., 2010. Zanieczyszczenie gleb miejskich miasta Łodzi wybranymi pierwiastkami śladowymi. Zeszyty Naukowe. Chemia spożywcza i Biotechnologia / Politechnika Łódzka 74, 29-38.

Niewiadomski, A., Tołoczko, W., 2005. Charakterystyka stanu środowiska glebowego w strefie oddziaływania wysypiska odpadów komunalnych w Zgniłym Błocie. Zesz. Probl. Post. Nauk Roln. 505, 273-279. https://www.researchgate.net/publication/313904703.

Niewiadomski, A., Tołoczko, W., 2009. Analysis of water quality of Bzura drainage area (Central Poland) in 1998-2007. Pridneprovsky Research Journal 10 (99), Dniepropietrowsk, 59-81. https://www. researchgate.net/publication/314390399.

Niewiadomski, A., Tołoczko, W., 2014. Characteristics of soil cover in Poland with special attention paid to the Łódź region, [w:] Marszał, T., Kobojek, E., (red.), Natural environment of Poland and it's protection. Wydawnictwo Uniwersytetu Łódzkiego, Łódź, 75-99. http://hdl.handle.net/11089/5595.
Niewiadomski, A., Tołoczko, W., Trawczyńska, A., 2010. Ocena oddziaływania składowiska odpadów komunalnych we wsi Zgniłe Błoto (powiat zgierski) na jakość wód podziemnych, [w:] Ziułkiewicz, M., (red.), Stan i antropogeniczne zmiany jakości wód w Polsce, 6, Wydawnictwo Wydziału Nauk Geograficznych, Łódź, 119-130. https://www.researchgate.net/publication/314044798.

Peng, C., Wang, M., Chen, W., Chang, A.C., Crittenden, J.C., 2017. Mass balance-based regression modeling of $\mathrm{Cd}$ and $\mathrm{Zn}$ accumulation in urban soils of Beijing. Journal of Environmental Sciences 53, 99-106. DOI: 10.1016/j.jes.2016.05.012.

Qing, X., Yutong, Z., Shenggao, L., 2015. Assessment of heavy metal pollution and human health risk in urban soils of steel industrial city (Anshan), Liaoning, Northeast China. Ecotoxicology and Environmental Safety 120, 377-385. DOI: 10.1016/j.ecoenv.2015.06.019.

Sobolewski, Ł., Tołoczko, W., 2007. Charakterystyka współczesnego zagospodarowania doliny Dobrzynki na obszarze gminy Tuszyn, [w:] Tołoczko, W., (red.), Zagospodarowanie dolin rzecznych. Wydawnictwo Piktor, Łódź, 77-84. http://hdl.handle.net/11089/20764.

Tołoczko, W., Niewiadomski, A., Trawczyńska, A., 2009. Influence of salinity on the sorptive features in soils of Lodz city centre. Ecological Chemistry and Engineering A 16 (4), 465-474. https://www. researchgate.net/publication/313919217.

Trawczyńska, A., Tołoczko, W., 2005a. Content of heavy metals in ground water of the soil of Bzura River Valley. Chemia i Inżynieria Ekologiczna 12 (1-2), 121-126. https://www.researchgate.net/ publication/313878100.

Trawczyńska, A., Tołoczko, W., 2005b. Zawartość i profilowe rozmieszczenie siarki ogólnej i siarki siarczanowej w glebach użytków zielonych Doliny Bzury. Inżynieria Ekologiczna 12, 315-316. https:// www.researchgate.net/publication/314232174.

Trawczyńska, A., Tołoczko, W., 2006. Content and profile arrangement of total and sulphate sulphur in soils of greenlands of Bzura River Valley. Ecological Chemistry and Engineering 13 (1-2), 139-145. https://www.researchgate.net/publication/314240421.

Trawczyńska, A., Tołoczko, W., Niewiadomski, A., 2009. Zawartość pierwiastków śladowych w wodach górnej Bzury. Ochrona Środowiska i Zasobów Naturalnych 40, Warszawa, 491-496. http://www.ios. edu.pl/pol/pliki/nr40/nr40_58.pdf.

Urbański, J., 2012. GIS w badaniach przyrodniczych. Wydawnictwo Centrum GIS, Uniwersytet Gdański, 1-266.

Wroński, K., Tołoczko, W., 2008. Dziedzictwo nawodnień doliny Neru szansą na rozwój hodowli, [w:] Tołoczko, W., (red.), Dziedzictwo kulturowe, ochrona i adaptacja jako szansa na rozwój. Wydawnictwo Piktor, Łódź, 108-118. http://hdl.handle.net/11089/20792. 